\title{
Electroencephalography (EEG) and Syncope: A Retrospective Study
}

\author{
Elektroensefalografi (EEG) ve Senkop: \\ Retrospektif Bir Çalışma
}

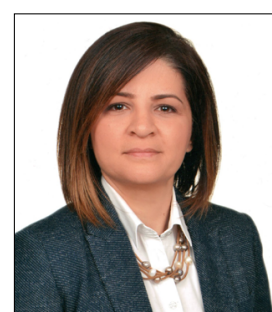

Dr. Bahar SAY

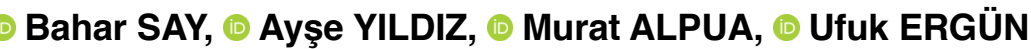

Department of Neurology, Kırıkkale University Faculty of Medicine, Kırıkkale, Turkey

\section{Summary}

Objectives: Electroencephalography (EEG) is one of the most vital tools in neurology practice. It is used for the diagnosis and differential diagnosis of several clinical conditions. One of them is syncope. In this study, it was planned that a retrospective evaluation of EEGs performed due to syncope in our laboratory and determine the rate of abnormal EEGs.

Methods: EEG recordings performed due to syncope were reviewed over a two-years period in this study. The EEG findings were classified as normal and abnormal. The abnormal EEG findings were classified into focal epileptiform discharge, generalized epileptiform discharge, focal slowing and generalized slowing subgroups and analyzed.

Results: The results of 298 EEGs were analyzed, which involved 174 (58.3\%) female and 124 (41.6\%) male subjects, with a mean age of $38.84 \pm 17.83$ (min-max: 17-90) years. Among subjects with syncope, $90.6 \%$ of the EEGs were normal and $9.4 \%$ showed abnormal findings. The most common abnormal finding was focal epileptiform discharge (5.03\%). Generalized epileptiform discharge was observed in three (1\%), focal slowing in seven (2.3\%) and generalized slowing in two (0.6\%) subjects. Among the EEG results with no abnormal findings, 38 (12.7\%) had sleep-deprived EEG and six (2.1\%) were found to have focal epileptiform discharge. A total of $113(37.9 \%)$ subjects had electrocardiogram recording and results were normal.

Conclusion: The rate of abnormal findings in EEGs performed due to syncope is low. EEG may be helpful in some selected subjects with syncope referred to the laboratory with a good history and neurological examination. EEG may be repeated if necessary.

Keywords: Consciousness; EEG; epilepsy; epileptiform discharge; syncope.

\section{Özet}

Amaç: Elektroensefalografi (EEG) nöroloji pratiğinde önemli yere sahip araçlardan biridir. Birçok klinik durumun tanı ve ayırıcı tanısında kullanılabilmektedir. Bunlardan biri de senkoptur. Bu çalışmada, senkop nedeniyle laboratuarımızda çekilen EEG'lerin retrospektif değerlendirilmesi ve anormal EEG oranının belirlenmesi planlandı.

Gereç ve Yöntem: Senkop nedeniyle çekilen iki yıllık EEG kayıtları retrospektif olarak gözden geçirildi. Olguların EEG sonuçları normal (anormal bulgu içermeyen) ve anormal olarak sınıflandırıldı. Anormal olan EEG sonuçlarında fokal epileptiform deşarj, jeneralize epileptiform deşarj, fokal yavaş, jeneralize yavaş olarak alt gruplara bakıldı.

Bulgular: Bu çalışmaya 298 EEG dahil edildi. Çalışmada 174 (\%58.3) kadın, 124 (\%41.6) erkek olup yaş ortalaması $38.84 \pm 17.83$ (min-maks: 17-90) oldu. Senkoplu olgular arasında EEG'lerin \%90,6'sı normal, \%9.4'ü anormaldi. En sık fokal epileptiform deşarj (\%5.03) izlendi. Jeneralize epileptiform deşarj üç (\%1), fokal yavaşlama yedi (\%2.3), jeneralize yavaşlama iki (\%0.6) olguda izlendi. Anormal bulgu içermeyen EEG'ye sahip olguların 38'ine (\%12,7) uyku deprivasyonlu EEG çekilmişti ve altısında (\%2.1) fokal epileptiform deşarj saptanmıştı. Toplamda 113 (\%37.9) olguda eş zamanlı elektrokardiografi kayıdı vardı ve sonuçları normaldi.

Sonuç: Senkop nedeniyle çekilen EEG'lerde anormal bulgu oranı düşüktür. İyi bir öykü ve nörolojik muayene ile laboratuara yönlendirilen seçilmiş bazı senkop olgularında EEG faydalı olabilir. Gerekirse EEG tekrar edilebilir.

Anahtar sözcükler: Bilinç; EEG; epilepsi; epileptiform deşarj; senkop. 


\section{Introduction}

Electroencephalography (EEG) is a neurophysiological test that is easy to perform and that is in common use in neurology practice. The technology is quite old, with the first human EEG recording performed by Hans Berger, known as the father of EEG. In 1924, Berger, with a colleague, placed electrodes directly on the cortex of the patient during surgery and made recordings from the scalp. ${ }^{[1]}$ EEG records cerebral electrical oscillations through electrodes placed on the scalp, making it possible to observe diffuse and focal changes in electrical activity that can be affected by the disease, along with the normal activity. In practice, patients are referred to EEG most often after a suspected epileptic seizure, focal lesions, encephalopathies and changes in consciousness. ${ }^{[2]}$ Syncope subjects involving a complete loss of consciousness account for some of the subjects referred for EEG.

Syncope is a frequent syndrome that is characterized by a temporary loss of consciousness and postural tonus due to global cerebral hypoperfusion. Its incidence is not precisely known due to terminological differences and unreported subjects, but its lifetime prevalence varies from $20 \%$ to $60 \%$. Syncope may occur at any age, with the most common type being neurally mediated syncope (neurocardiogenic syncope, vasovagal syncope and vasodepressor syncope). [3] Patients are typically referred to a cardiologist due to possibility of life-threatening heart diseases, although the etiology is usually not clear. Accordingly, subjects may be consulted by a neurologist for neurological diseases, such as epilepsy with temporary loss of consciousness and transient ischemic attack. After clinical history and examinations, EEG may be one of the most informative laboratory examinations.

This study was planned to identify the rate and types of abnormal findings in subjects where EEG is requested after an investigation of the etiology of syncope.

\section{Materials and Methods}

Electroencephalography recordings of the adult subjects referred to the EEG laboratory of the neurology department in the tertiary center were examined retrospectively by the two neurologists from July 2017 to April 2019. The use of psychiatric drugs that may affect EEG and severe mental retardation were excluded in subjects in this study.
EEG recordings that included more artifact, short-term record ( $<20$ minutes) and without induction methods, such as photic stimulation and hyperventilation, were also excluded.

Scalp surface electrodes of EEG were placed according to the 10-20 system of the international federation and record was done using 21 channel Nihon Kohden EEG recorder. Results of the EEG were classified as normal and abnormal. EEG was considered abnormal if it contained focal epileptic discharge, generalized epileptic discharge, generalized slowing or focal slowing. Because of possible different proportions of diseases across the ages, three groups were created according to age (years) ranges as follows: Group 1 (17-25), Group 2 (26-50), Group 3 ( $\geq 51)$. There was no EEG record under the age of 17.

Statistical analysis was carried out using SPSS 21 package program. (SPSS Inc., Chicago, III, USA). Independent-sample t-tests and chi-square (Pearson) test were used statistically, and $p$-values $<0.05$ were accepted as significant.

\section{Results}

A total of 340 EEG recordings were examined and 298 EEG results were included according to exclusion criteria. There were 174 females (58.3\%) and 124 males (41.6\%) and the mean age was $38.84 \pm 17.83$ (min-max: 17-90) in the study population. Among all EEG results, 270 (90.6\%) were normal and 28 (9.4\%) were abnormal. Total 18 female and 10 male subjects were in abnormal EEG results $(p=0.506)$.

There were 108 subjects in Group 1, 106 subjects in Group 2 and 84 subjects in Group 3. Demographic characteristics and EEG results of the groups are summarized in Table 1.

Abnormal EEG results are shown in Table 2. Focal epileptiform discharge (15 subjects, 5.03\%) was the most common abnormal EEG finding. Generalized epileptiform discharge was observed only in three subjects (1\%) in Group 1. Focal slowing was highest in Group 2 (5 subjects). Generalized slowing was observed only in Group 3.

Focal frontal epileptiform discharge was observed in seven subjects, temporal discharge in five subjects, parietal discharge in two subjects and occipital discharge in one subject in focal epileptiform findings. 
Table 1. Demographic characteristics and EEG results of the groups

\begin{tabular}{lcccc}
\hline & Group 1 $(\mathrm{n}=108)$ & Group 2 $(\mathrm{n}=106)$ & Group 3 $(\mathrm{n}=84)$ & p value \\
\hline $\begin{array}{l}\text { Age group } \\
\text { Gender, } n(\%)\end{array}$ & $17-25$ & $26-50$ & $\geq 51$ & \\
$\quad$ Female & $67(38.5)$ & $69(39.7)$ & $38(21.8)$ & 0.14 \\
$\quad$ Male & $41(33.1)$ & $37(29.8)$ & $46(37.1)$ & \\
EEG, $n$ (\%) & & & & \\
$\quad$ Normal & $95(35.2)$ & $95(35.2)$ & $80(29.6)$ & 0.21 \\
$\quad$ Abnormal & $13(46.4)$ & $11(39.3)$ & $4(14.3)$ & \\
\hline
\end{tabular}

EEG: Electroencephalography.

Table 2. Abnormal EEG results according to gender and group

\begin{tabular}{lcccc}
\hline & $\begin{array}{c}\text { Focal epileptiform } \\
\text { discharge }\end{array}$ & $\begin{array}{c}\text { Generalized epileptiform } \\
\text { discharge }\end{array}$ & $\begin{array}{c}\text { Focal } \\
\text { slowing }\end{array}$ & $\begin{array}{c}\text { Generalized } \\
\text { slowing }\end{array}$ \\
\hline $\begin{array}{l}\text { Number, } \mathrm{n} \\
\text { Age (mean } \pm \text { SD) }\end{array}$ & 15 & 3 & 7 & 3 \\
Abnormality in groups, $\mathrm{n}(\%)$ & $29.53 \pm 14.24$ & $19.67 \pm 1.52$ & $41.98 \pm 15.3$ & $75.99 \pm 2.12$ \\
$\quad$ Group 1 & $8(53.3)$ & $3(100)$ & $1(14.3)$ & - \\
$\quad$ Group 2 & $6(40)$ & - & $5(71.4)$ & - \\
$\quad$ Group 3 & $1(6.6)$ & - & $1(14.3)$ & $3(100)$ \\
Gender, $\mathrm{n}$ & & & & 1 \\
$\quad$ Female & 10 & 1 & 5 & 1 \\
Male & 5 & 2 & 2 & \\
\hline
\end{tabular}

Group 1: 17-25 age group, Group 2: 26-50 age group, Group 3: $\geq 51$ age group. EEG: Electroencephalography; SD: Standard deviation.

EEG was recorded the second time in 38 (13.1\%) of the subjects with normal EEG. Focal epileptiform discharge was found in six (2.2\%) of these subjects.

Simultaneous electrocardiogram was recorded in 113 (37.9\%) of the total subjects and results were normal. In addition, hemispheric asymmetry was not observed in all EEGs.

\section{Discussion}

In the present study, abnormal EEG findings were detected in $9.4 \%$ of the subjects suffering from syncope, with no abnormal findings identified in $90.6 \%$. The most common (5.3\%) abnormal finding was the focal epileptiform abnormality.

Among the studies making retrospective evaluations of EEGs performed for syncope etiology purposes in the literature, the study by Abubakr et al. ${ }^{[4]}$ identified normal findings in $67.18 \%$ and abnormal (focal or diffuse slowing, $28.15 \%$; epileptiform discharge, $1.4 \%$ ) findings in $29.6 \%$ of the 1094
EEG recordings of syncope subjects. In the aforementioned study, the age range was $6-10$ years $(67.7 \%>60$ years). Aside from two subjects, EEG was found to be normal in all subjects under the age of 20 . The study conducted by Dantas et al., ${ }^{[5]}$ analyzing EEG recordings of a large syncope group (1003 subjects) with an age range of 1-94 years reported normal findings in $89.53 \%$, and abnormal findings (diffuse/focal slowing, 8.5\%; epileptiform discharge, 1.79\%) in $10.5 \%$. Since causes may vary by etiology, the authors grouped the participants by age and reported the most common diffuse slowing in the $26-50$ years and $>51$ years age groups. Among the studies evaluating a low number of syncope subjects, the study carried out by Nalbantoglu et al., ${ }^{[6]}$ which added hemispheric asymmetry and low-amplitude to the abnormal findings, reported that $70.5 \%$ of the EEG recordings of 288 adult subjects were normal and $29.5 \%$ were abnormal (low-amplitude, 16.3\%; focal/diffuse slowing, 5.4\%; epileptiform discharge, 4.5\%; hemispheric asymmetry, 3.5\%). Low-amplitude EEG was found to be the most common abnormal finding. The retrospective analysis carried out by Poliquin-Lasnier et al. ${ }^{[7]}$ on the EEG recordings 
of 517 adult syncope subjects with a mean age of 58 years reported abnormalities at a rate of $11.7 \%$ (focal slowing, $8 \%$; generalized slowing, 3\%; potential epileptic, 1.3\%). An older study with a limited number of syncope subjects (73 subjects) reported the abnormal EEG rate as $13.7 \% .^{\left[{ }^{[8]}\right.}$ Based on such findings, it has been remarked in the literature that EEG plays a small part in syncope subjects, in which epileptiform abnormality rates resemble those of healthy adult EEGs. ${ }^{[5,9]}$ Focal/diffuse slowing was found to be the most common form, although concurring with literature, the present study established a low rate of abnormal EEG. Female subjects with abnormal EEG were more than men. This may be due to a large number of female subjects in the study population.

In syncope subjects, a good history and a neurological examination can prevent unnecessary analysis and reduce costs. In addition to EEG, which is thought to be low in syncope, other neuroimaging applications with a low diagnostic value for syncope may also contribute to increased costs. ${ }^{[10]}$ It has been pointed out, however, that EEG examinations are requested more than required in epilepsy subjects. ${ }^{[11]} \mathrm{A}$ previous study evaluating all outpatient subjects referred to a tertiary EEG laboratory reported a high rate (66.7\%) of normal EEG and a low rate of (13.2\%) epileptiform discharge. ${ }^{[12]}$ Likewise, a study from Ireland, in which EEG recordings performed at a tertiary reference center were analyzed retrospectively. It was reported that EEG had been requested more than necessary. ${ }^{[13]}$ In another study, in which an inpatient group examined the contribution of EEG to other medical conditions, reported that EEG might have contributed rather to the diagnosis and treatment of seizure and epilepsy. ${ }^{[14]}$ A study conducted in a general inpatient population, in turn, reported that more frequent seizures were likely to be observed in patients with accompanying changes in consciousness, and stated that EEG was a diagnostic tool used at a lower rate than required in such subjects. ${ }^{[15]}$

From a different standpoint, pathology may not always be observable on EEG at all times, despite the clues suggesting epileptic seizure in the history of subjects with paroxysmal attacks. It has been previously reported that subjects with suspected epileptic seizures may have a normal EEG at a rate of $12-50 \% .{ }^{[16,17]}$ In such a subject, repeated EEGs or longer recording times increase the possibility of recording the epileptiform activities. ${ }^{[18]}$ Furthermore, hyperventilation, photic stimulation or sleep-deprived EEG are likely to activate epileptiform discharge.$^{[19]}$ In the present study, new subjects (6 subjects) with abnormal findings (focal epileptiform discharge) emerged when the EEG was repeated.

The present study observed focal epileptiform discharge as the most common abnormality on EEGs performed for the syncope etiology. That said, the most common abnormality was not focal/diffuse slowing, and differed from literature with being a focal epileptiform abnormality. The reason for this difference may be that the number of EEGs evaluated and the abnormality in other studies were evaluated as epileptiform discharge (without focal/generalized distinction). Slow-wave abnormality is more common among the advanced age group, and the numbers of subjects under the age of 51 are considerably higher than the number of those above the age of 51 may have also played a role in this finding. Focal epileptiform discharges are most commonly located in the frontal region. The semiology of frontal lobe epilepsies is not always easy and can be mixed with neurological presentations, such as paroxysmal neurological disorders and syncope. In such subjects, the EEG plays an important role in the diagnosis process. ${ }^{[20]}$ During the imaging of the brains of the subjects with a focal epileptiform discharge, only and the subject was observed to have a temporal arteriovenous malformation (AVM), and other subjects were normal. In addition, antiepileptic drugs were started to nine of the patients with focal epileptiform discharges. Other suspicious subjects were followed up. Interictal epileptiform discharge can be observed in approximately $2 \%$ of the healthy individuals without a history of epileptic seizures. ${ }^{[2]]}$

In neurology practice, EEG may serve as a diagnostic tool for several conditions, and in particular, for seizure and epilepsy, but EEG may gain more importance if a good history and detailed neurological examination are performed first in the selected some subjects with syncope referred to the laboratory and others. In some subjects, it can be repeated. This study, can be effective in reminding of the efficient use of the EEG and laboratory as valuable assets for neurologists.

\section{Ethics Committee Approval}

Ethics committee approved.

\section{Peer-review}

Externally peer-reviewed.

\section{Conflict of interest}

The authors declare that they have no conflict of interest. 


\section{Authorship Contributions}

Concept: B.S., U.E.; Design: B.S., A.Y.; Supervision: U.E.; Materials: B.S., M.A.; Data collection \&/or processing: B.S., A.Y., M.A.; Analysis and/or interpretation: B.S.; Literature search: B.S., A.Y.; Writing: B.S.; Critical review: U.E.

\section{References}

1. Macarelli O. Past, present, future of the EEG. In: Macarelli O, editor. Clinical encephalography. Switzerland: Springer; 2019. p. 3-9. [CrossRef]

2. Writton JR. Adult encephalography, abnormal nonepileptiform activity. In: Rubin DV, Daube JR, editors. Cinical Neurophsiology. 4th ed. USA: Oxford University Press; 2009. p. 51-75.

3. Cheshire WP Jr. Syncope. Continuum (Minneap Minn) 2017;23(2):335-8. [CrossRef]

4. Abubakr A, Wambacq I. The diagnostic value of EEGs in patients with syncope. Epilepsy Behav 2005;6(3):433-4. [CrossRef]

5. Dantas FG, Cavalcanti AP, Rodrigues Maciel BD, Ribeiro CD, Napy Charara GC, Lopes JM, et al. The role of EEG in patients with syncope. J Clin Neurophysiol 2012;29(1):55-7. [CrossRef]

6. Nalbantoglu M, Tan OO. The yield of electroencephalography in syncope. Ideggyogy Sz 2019;72(3-4):111-4. [CrossRef]

7. Poliquin-Lasnier L, Moore FG. EEG in suspected syncope: do EEGs ordered by neurologists give a higher yield? Can J Neurol Sci 2009;36(6):769-73. [CrossRef]

8. Davis TL, Freemon FR. Electroencephalography should not be routine in the evaluation of syncope in adults. Arch Intern Med 1990;150(10):2027-9. [CrossRef]

9. Jabbari B, Russo MB, Russo ML. Electroencephalogram of asymptomatic adult subjects. Clin Neurophysiol 2000;111(1):1025. [CrossRef]

10. Pournazari P, Oqab Z, Sheldon R. Diagnostic Value of Neurological Studies in Diagnosing Syncope: A Systematic Review. Can J

\section{Cardiol 2017;33(12):1604-10. [CrossRef]}

11. Fowle AJ, Binnie CD. Uses and abuses of the EEG in epilepsy. Epilepsia 2000;41(3):10-8. [CrossRef]

12. Monif $M$, Seneviratne $U$. Clinical factors associated with the yield of routine outpatient scalp electroencephalograms: A retrospective analysis from a tertiary hospital. J Clin Neurosci 2017;45:110-4. [CrossRef]

13. O'Toole O, Lefter S, McNamara B. EEG use in a tertiary referral centre. Ir Med J 2011;104(7):202-4.

14. Theitler J, Dassa D, Gandelman-Marton R. How valuable is inpatient electroencephalogram for medical decision-making? Eur J Clin Invest 2016;46(12):1012-6. [CrossRef]

15. Betjemann JP, Nguyen I, Santos-Sanchez C, Douglas VC, Josephson SA. Diagnostic yield of electroencephalography in a general inpatient population. Mayo Clin Proc 2013;88(4):32631. [CrossRef]

16. van Donselaar CA, Schimsheimer RJ, Geerts AT, Declerck AC. Value of the electroencephalogram in adult patients with untreated idiopathic first seizures. Arch Neurol 1992;49(3):231-7.

17. Goodin DS, Aminoff MJ. Does the interictal EEG have a role in the diagnosis of epilepsy? Lancet 1984;1(8381):837-9.

18. Salinsky M, Kanter R, Dasheiff RM. Effectiveness of multiple EEGs in supporting the diagnosis of epilepsy: an operational curve. Epilepsia 1987;28(4):331-4. [CrossRef]

19. Badawy RA, Curatolo JM, Newton M, Berkovic SF, Macdonell RA. Sleep deprivation increases cortical excitability in epilepsy: syndrome-specific effects. Neurology 2006;67(6):1018-22.

20. Tatum WO, Rubboli G, Kaplan PW, Mirsatari SM, Radhakrishnan $\mathrm{K}$, Gloss D, et al. Clinical utility of EEG in diagnosing and monitoring epilepsy in adults. Clin Neurophysiol 2018;129(5):105682. [CrossRef]

21. Chen $H$, Koubeissi MZ. Electroencephalography in Epilepsy Evaluation. Continuum (Minneap Minn) 2019;25(2):431-53. 